\title{
Evaluation of the ethanolic extract of Myconia albicas (Old Cinnamon) in the alternative model of anxiety in zebrafish
}

\author{
A valiação do extrato etanólico de Myconia albicas (Old Cinnamon) no modelo alternativo de \\ ansiedade em peixes-zebra \\ Evaluación del extracto etanólico de Myconia albicas (Old Cinnamon) en el modelo alternativo de
} ansiedad en pez cebra

Received: 12/23/2021 | Reviewed: 12/29/2021 | Accept: 01/11/2022| Published: 01/13/2022

\author{
Fernanda Mota de Castro \\ ORCID: https://orcid.org/0000-0001-5330-9288 \\ Christus University Center, Brazil \\ E-mail: fe_fisio@outlook.com \\ Aimê Veras Alexandre \\ ORCID: https://orcid.org/0000-0002-3949-6483 \\ University of Fortaleza, Brazil \\ E-mail: aimeeveras@hotmail.com \\ Francisco Lucas Alves Batista \\ ORCID: https://orcid.org/0000-0002-7543-057X \\ Regional University of Cariri, Brazil \\ E-mail: Flucasbatista@outlook.com \\ Sacha Aubrey Alves Rodrigues Santos \\ ORCID: https://orcid.org/0000-0002-4117-2277 \\ University of Fortaleza, Brazil \\ E-mail: sachaaubrey@ hotmail.com \\ Francisco Rogênio da Silva Mendes \\ ORCID: https://orcid.org/0000-0001-8357-6707 \\ Ceara State University, Brazil \\ E-mail: rogenio10@yahoo.com.br \\ Ana Cristina de Oliveira Monteiro-Moreira \\ ORCID: https://orcid.org/0000-0002-3606-6808 \\ University of Fortaleza, Brazil \\ E-mail: acomoreira@unifor.br \\ Francisco Ernani Alves Magalhães \\ ORCID: https://orcid.org/0000-0002-4924-2882 \\ Ceara State University, Brazil \\ E-mail: fernanimagalhaes@yahoo.com.br \\ José Eduardo Ribeiro Honório Júnior \\ ORCID: https://orcid.org/0000-0001-8320-8525 \\ Christus University Center, Brazil \\ E-mail: Jose.ribeiro@unichristus.edu.br \\ Adriana Rolim Camposa \\ ORCID: https://orcid.org/0000-0003-0499-2660 \\ University of Fortaleza, Brazil \\ E-mail: adrirolim@unifor.br
}

\begin{abstract}
Myconia albicans is the most abundant genus of the melastomaceous botanical family. In Brazil, it is known as "Canela de Velho", and is used mainly in inflammatory processes. Due to the scarcity of scientific works that report its pharmacological effect, the objective of this study was to perform its chemical characterization, toxicity, and the possible effect on the nervous system, using the experimental model Zebrafish (Dario regio). The organic extract of ethyl acetate (EtOAc) was elaborated through the dry leaves of the cinnamon tree of old. The EtOAc sample was submitted to preliminary phytochemical screening and showed the presence of phenols, flavanoids of the flavones type, flavonols and xanthones, triterpenoids, and alkaloids. Then, flavonoid compounds $(369.58 \pm 0.074 \mathrm{mgEQ} / \mathrm{g}) \mathrm{and}$ total phenols $(81.48 \pm 0.005 \mathrm{mgEAG} / \mathrm{g})$ were determined. EtOAc was evaluated for its toxicity, with Artemia salina, which showed low toxicity in all the studied doses. In the pharmacological action tests, the doses of 3 , 10, or 30 $\mathrm{mg} / \mathrm{mL}$ were used; $20 \mu \mathrm{L}$; oral (v.o.) or intraperitoneal (i.p.). The locomotor activity was evaluated in the open field test, which showed a decrease in the fish. And the anxiolytic activity, in the light \& dark preference test, showed that EtOAc at $30 \mathrm{mg} / \mathrm{mL}$, when administered intraperitoneally (IP), has an anxiolytic effect similar to Diazepam IP
\end{abstract}


control. Thus the EtOAC of M. albicans showed the presence of total phenols and several flavonoids, with low toxicity, in which the highest dose presented anxiolytic effect in Zebrafish.

Keywords: Miconia albicans; Zebrafish; Anxiolytic.

\section{Resumo}

Myconia albicans é o gênero mais abundante da família botânica melastomaceous. No Brasil, é conhecido como "Canela de Velho", e é usado, principalmente, em processos inflamatórios. Devido à escassez de trabalhos científicos que relatem seu efeito farmacológico, o objetivo deste estudo foi realizar sua caracterização química, sua toxicidade e seu possível efeito no sistema nervoso, utilizando o modelo experimental Peixe-zebra (Dario regio). O extrato orgânico de acetato de etila (EtOAc) foi elaborado por meio das folhas secas da canela de antigamente. A amostra de EtOAc foi submetida a uma triagem fitoquímica preliminar e evidenciou a presença de fenóis, flavonoides do tipo flavonas, flavonóis e xantonas, triterpenoides e alcaloides. Em seguida, os compostos flavonoides (369,58 \pm $0,074 \mathrm{mgEQ} / \mathrm{g})$ e fenóis totais $(81,48 \pm 0,005 \mathrm{mgEAG} / \mathrm{g})$ foram determinados. O EtOAc foi avaliado quanto à sua toxicidade, juntamente com Artemia salina, que apresentou baixa toxicidade em todas as doses estudadas. Nos testes de ação farmacológica, foram utilizadas as doses de 3, $10 \mathrm{ou} 30 \mathrm{mg} / \mathrm{mL} ; 20 \mu \mathrm{L}$; oral (v.o.) ou intraperitoneal (i.p.). A atividade locomotora foi avaliada no teste de campo aberto, que mostrou diminuição dos peixes. E a atividade ansiolítica, no teste de preferência claro e escuro, mostrou que o EtOAc a $30 \mathrm{mg} / \mathrm{mL}$, quando administrado por via intraperitoneal (IP), tem efeito ansiolítico semelhante ao controle do Diazepam IP. Assim, o EtOAC de M. albicans mostrou a presença de fenóis totais e diversos flavonoides, com baixa toxicidade, em que a maior dose apresentou efeito ansiolítico no peixe-zebra.

Palavras-chave: Miconia albicans; Peixe-zebra; Ansiolítico.

\section{Resumen}

Myconia albicans es el género más abundante de la familia botánica de las melastomeas. En Brasil, se le conoce como "Canela de Velho" y se utiliza principalmente en procesos inflamatorios. Debido a la escasez de trabajos científicos que reporten su efecto farmacológico, el objetivo de este estudio fue realizar su caracterización química, su toxicidad y su posible efecto sobre el sistema nervioso, utilizando el modelo experimental Pez cebra (Dario regio). El extracto orgánico de acetato de etilo (EtOAc) se elaboró a través de las hojas secas de la canela de antaño. La muestra de EtOAc fue sometida a un cribado fitoquímico preliminar y mostró la presencia de fenoles, flavonoides del tipo flavonas, flavonoles y xantonas, triterpenoides y alcaloides. Luego, se determinaron los compuestos flavonoides $(369,58 \pm 0,074 \mathrm{mgEQ} / \mathrm{g})$ y los fenoles totales $(81,48 \pm 0,005 \mathrm{mgEAG} / \mathrm{g})$. Se evaluó la toxicidad de EtOAc, con Artemia salina, que mostró baja toxicidad en todas las dosis estudiadas. En las pruebas de acción farmacológica, se utilizaron las dosis de 3,10 o $30 \mathrm{mg} / \mathrm{mL} ; 20 \mu \mathrm{L}$; oral (v.o.) o intraperitoneal (i.p.). La actividad locomotora se evaluó en la prueba de campo abierto, que mostró disminución de los peces. Y la actividad ansiolítica, en la prueba de preferencia de luz y oscuridad, mostró que EtOAc a $30 \mathrm{mg} / \mathrm{mL}$, cuando se administra por vía intraperitoneal (IP), tiene un efecto ansiolítico similar al control de Diazepam IP. Así, la EtOAC de M. albicans mostró la presencia de fenoles totales y varios flavonoides, de baja toxicidad, en los que la dosis más alta presentó efecto ansiolítico en el pez cebra.

Palabras clave: Miconia albicans; Pez cebra; Ansiolítico.

\section{Introduction}

Anxiety is the most common psychiatric disorder. WHO data show a worldwide prevalence of this disease in the order of 3.6\%. In the American continent, it reaches 5.6\% and in Brazil it is present in 9.3\% of the population, with the highest number of cases among countries in the world (Ferreira et al., 2017; Garakani et al., 2020; Mufford et al., 2021)

Classic pharmacological therapy in the treatment of anxiety is based on the use of traditional anxiolytic/hypnotic agents, such as benzodiazepines, which have numerous undesirable side effects (Bezerra et al., 2017; Penninx et al., 2021; Reis et al., 2017). In 2006, the National Policy of Integrative and Complementary Practices (PICS) and the National Policy of Medicinal Plants and Phytotherapies were implemented in the Brazilian Unified Health System (Brasil. Ministério da Saúde, 2004, 2014; Figueredo et al., 2014).

The Myconia albicans, populously known as "Old Cinnamon or Canela de Velho", is a species of the Brazilian cerrado and is the most abundant genus of the botanical family melastomatacea, with 4,300 species. The leaves of "Canela de Velho" are widely used in popular medicine, being sold in fairs and stores of natural products and used to treat gastric 
disorders, rheumatoid arthritis and bacterial infections (Celotto et al., 2003; De Oliveira Viana Arruda et al., 2008; Lima et al., 2020; Vasconcelos et al., 2006).

Zebrafish (Danio rario Hamilton 1822) is a teleosteal freshwater fish $(2.0 \mathrm{~cm}$ long and weighing around $1.5 \mathrm{~g})$, and is considered an ideal alternative model for human disease research. Zebrafish (or Paulistinha do Brasil) has an environment of $70 \%$ genetic homology with human beings, besides other advantages such as low cost, easy handling and maintenance, little space for maintenance, fast embryonic development, and its behavior can be easily observed and quantified (Canedo \& Rocha, 2021; Maximino et al., 2010; Mesquita et al., 2017; Sborgi et al., 2021; Stewart et al., 2013).

As the tea from the leaves of Miconia albicans has been widely used by the Brazilian population because of its antiinflammatory effects, and the anxiety presents in its mechanisms inflammatory components, this study aimed to evaluate the pharmacological potential of the ethanolic extract extracted from the leaves of Miconia albicans, commercialized in the city of Fortaleza, in the treatment of anxiety in zebrafish models.

\section{Methodology}

\subsection{Preparation of extracts}

Samples of the ethanolic organic extract of ethyl acetate from the old cinnamon (EtOAc) were extracted from the dried leaves acquired commercially (Chás da Amazônia, Lot: 138) in a natural products store in the city of Fortaleza. The acquisition of EtOAc followed the parameters of Matos' methodology (Lorenzi \& Matos, 2002), since, for the author, "every 70 grams of cinnamon leaves samples of old people, three liters of EtOAc solvent are used".

\subsection{Phytochemical profile}

EtOAc was subjected to a preliminary phytochemical screening in order to identify secondary metabolites. The compounds present in the samples were shown as present (+) or absent (-) (Lorenzi \& Matos, 2002).

\subsubsection{Total phenolic compounds and content of total flavonoids}

The phenolic compounds were determined using the Folin-Ciocalteu method, in which the reference parameter is gallic acid (Slinkard \& Singleton, 1977).

The characterization of the total flavonoid content was done according to Sousa et al. (Sousa et al., 2015) using the aluminium method. The absorbances were read by the spectrophotometer at $415 \mathrm{~nm}$, and all tests were done in triplicate. The results were displayed as mean \pm standard deviation (SD), and the correlation coefficient defined using Excel Software (Lemos et al., 2011).

\subsection{Toxicity and Behavioral Studies of the Ethanolic Extract of Myconia albicans}

\subsubsection{In vitro toxicity}

We used 10 nauplii in larval state of Artemia salina, conditioned in the microplate 96 wells with the ethanolic extract in the following concentrations: 100, 500 and $1000 \mu \mathrm{g} / \mathrm{mL}$ (Meyer, Ferrigni, \& Putnam, 1982). After 24 hours, CL50 (lethal concentration for $50 \%$ of the nauplii) was calculated, being the toxic potentials classified as non-toxic/toxic.

\subsubsection{Behavioral Models of Anxiety in Zebrafish}

Adult wild zebrafish of both sexes aged 60-90 days were obtained from Agroquímica: Comércio de Produtos Veterinários LTDA, a supplier in Fortaleza (Ceará,Brazil). All experimental procedures were approved by the Ethics Committee on Animal Research of the Ceará State University (CEUA-UECE). The protocol was filed under No. 
7210149/2016. They were conditioned in a 10 - $\mathrm{L}$ glass tank $(30 \mathrm{X} 15 \mathrm{X} 20 \mathrm{~cm})$ at $24^{\circ} \mathrm{C} \pm 2^{\circ} \mathrm{C}$ and $\mathrm{pH} 7,0$ with water treated with anticloro (ProtecPlus $\left.{ }^{\circledR}\right)$ and normal circadian rhythm (14h:10h of light/dark). Os animais foram divididos em grupos (n=6/ cada), onde: Grupo 1 - NAIVE ( sem tratamento) ; Grupo 2 - Controle - Dimetilsulfóxido (DMSO) ) (concentração de 3\%; 20 $\mu \mathrm{L}$ v.o/i.p); Grupo 3 - Diazepan (concentração de 2,5mg/mL; $20 \mu \mathrm{L}$ v.o/i.p); Grupo 4 - Solução do extrato (concentração 3mg/mL; $20 \mu \mathrm{L}$ v.o/i.p. ); Grupo 5 - Solução do extrato (concentração 10mg/mL; $20 \mu \mathrm{L}$ v.o/i.p. ); Grupo 6 - Solução do extrato (concentração $30 \mathrm{mg} / \mathrm{mL} ; 20 \mu \mathrm{L}$ v.o/i.p.).

\subsubsection{Open-field Test}

The locomotor activity was evaluated according to Magalhães et al.(Magalhães et al., 2017) After 1 hour of treatment time, the animals were placed in Petri dishes $(130 \mathrm{~mm}$ diameter), previously marked in four quadrants and immersed in $60 \mathrm{~mL}$ of water from the aquarium. The locomotor analysis was based on the number of crossings between the marked quadrants.

\subsubsection{Light-Dark Preference Test}

For the evaluation of the anxiolytic activity, the Clear \& Dark Test was used according to the methodology proposed by Gebauer et al (Gebauer et al., 2011). The administration of the drugs occurred 60 minutes before each test. The animals were then positioned in the light zone in a glass tank (height: $7.0 \mathrm{~cm}$; width: $9.0 \mathrm{~cm}$; length: $18.0 \mathrm{~cm}$; black side: $9.0 \mathrm{~cm}$ and white side: $8.0 \mathrm{~cm}$ ) with $3 \mathrm{~cm}$ of water, and evaluated within 5 minutes the following items: I) Latency time: interval of the first passage to the dark compartment; II) Time in the light: total time to stay in the light zone; III) Number of crossings: Total number of crossings made between the light and dark zones.

\section{Results}

\subsection{Yield of the extract}

Table 1 shows the yield of Ethyl Acetate extract from the Old Cinnamon after freeze-drying, in which, for each 70g of raw material, $3 \mathrm{~L}$ of solvent with a yield of $0.5314 \mathrm{~g}$ was used.

Table 1. Yields of cinnamon extract from old men (M. albicans). EtOAc - Ethyl acetate; obtained from lyophilized tea.

\begin{tabular}{ccccc}
\hline & & Plant material & \multicolumn{2}{c}{ Yield } \\
\cline { 3 - 5 } Extract & Solvent $(\mathbf{L})$ & weight $(\mathbf{g})$ & $(\mathbf{g})$ & $(\boldsymbol{\%})$ \\
\hline EtOAc & $3 \mathrm{~L}$ & 70 & 0,5314 & 0,76 \\
& & & & \\
\hline
\end{tabular}

Source: Authors.

\subsection{Preliminary photochemical screening}

The phytochemical analysis of EtOAc showed the presence of phenols, flavones type Flavanoids, flavonols and xanthones, flavanon as type Flavanoids, triterpenoids and alkaloids and absence of tannins, anthocyanin type Flavonoids, leukoanthocyanidin type Flavanoids, catechins, flavanonols type Flavanoids and steroids (Table 2). 
Table 2. Preliminary phytochemical analysis of EtOAc extract from cinnamon of old (M. albicans). CME1-phenols; CME2tanins; CME3-Flavanoids of the flavones, flavonols and xanthones type; CME4-Flavonoids of the anthocyanins and anthocyanidins type; CME5-Flavanoids of the leukoanthocyanidins type, catechins; CME6-Flavanoid flavanones; CME7Flavanoid flavanonols; CME8-steroids; CME9-triterpenoids; CME10-alkaloids; (+) - present; (-) - absent;

\begin{tabular}{|c|c|c|c|c|c|c|c|c|c|c|}
\hline \multirow{2}{*}{ Extract } & \multicolumn{10}{|c|}{ Specialty Metabolite Classes (CME) } \\
\hline & CME1 & CME2 & CME3 & CME4 & CME5 & CME6 & CME7 & CME8 & CME9 & CME10 \\
\hline EtOAc & + & - & + & - & - & + & - & - & + & + \\
\hline
\end{tabular}

\subsubsection{Determination of total phenolic compounds}

The concentration of phenolic compounds was reached after the standard gallic acid curve, which varied significantly $(p<0.05)$. (Table 3)

\subsubsection{Determination of the total flavonoid content}

The flavonoid content of EtOAc was measured using the aluminum method, using quercetin. The total flavonoid concentration was significant ( $\mathrm{p}<0.001$ ), from 0.61 to $369.58 \mathrm{mg}$ of EQuer/g of extract. (Table 3)

Table 3. Phenols and phalavonoids content of EtOAc extract from cinnamon of old (M. albicans). The data are presented as the content \pm standard deviation of the. Values with lowercase letters indicate that there was a significant difference $(* * \mathrm{p}$ $<0.01$ and ${ }^{* * *}$ p <0.001 vs control), Anova followed by Tukey. EtOAc - Ethyl acetate of M. albicans; EAG: equivalent to Gallic Acid;

\begin{tabular}{ccc}
\hline Extract & $\begin{array}{c}\text { Fenois } \\
(\mathbf{m g E A G} / \mathbf{g})\end{array}$ & $\begin{array}{c}\text { Flavonoides } \\
(\mathbf{m g E Q} / \mathbf{g})\end{array}$ \\
\cline { 2 - 3 } & $81,48 \mathrm{c} \pm 0,005^{* *}$ & $369,58 \mathrm{c} \pm 0,076^{* * *}$ \\
\hline
\end{tabular}

Source: Authors.

\subsection{Toxicity and Behavioral Studies of the Ethanolic Extract of Myconia albicans}

\subsubsection{Toxicity to Artemia salina}

The lethality test before Artemia salina did not cause mortality of $50 \%$ of the nauplii, confirming no toxicity in the sample, as illustrated in Table 4.

Table 4: EtOAc toxicity test results in Artemia salina. EtOAc - ethyl acetate extract; GCN1- negative control group 1: DMSO 3\%; GC2 - negative control group 2: isotonic saline solution; GCP3- positive control group 3: NaClO 1\%; CA1 - sample concentration $1(100 \mu \mathrm{g} / \mathrm{mL})$; CA2 - sample concentration $2(500 \mu \mathrm{g} / \mathrm{mL})$; CA3 - sample concentration $3(1.000 \mu \mathrm{g} / \mathrm{mL})$; CL50-lethal concentration to kill 50\% of Artemia salina nauplii; IV - confidence interval;

\begin{tabular}{|c|c|c|c|c|c|c|c|}
\hline \multirow{2}{*}{ Extract } & \multicolumn{6}{|c|}{ Mortality of $A$. salina larvae } & \multirow{2}{*}{$\operatorname{CL50}(\mu \mathrm{g} / \mathrm{mL}) / \mathrm{IV}$} \\
\hline & BCM1 & ВCM2 & GCP3 & CA1 & CA2 & CA3 & \\
\hline EtOAc & 1 & 0 & 30 & 4 & 0 & 0 & $>1000$ \\
\hline
\end{tabular}

Source: Authors. 


\subsubsection{Behavioral Models of Anxiety in Zebrafish}

\subsubsection{Open-field test (Locomotor behavior)}

The tests of locomotor activity with EtOAc via oral route in doses 10 and $30 \mathrm{mg} / \mathrm{mL} ; 20 \mu \mathrm{L}$ showed compromise in the locomotor system of the fish, since it reduced significantly $(\mathrm{p}<0.05$ or $\mathrm{p}<0.001$ vs. Naive) the locomotor activity of zebrafish $(\mathrm{AL}=35.9$ or $56.7 \%$ ) (Figure 1$)$.

Figure 1 Locomotor activity of adult zebrafish (Danio rerio) in the Open Field Test. Naive - untreated animals; Vehicle mineral H2O (20 $\mu \mathrm{L}$; v.o.) or DMSO 3\% (20 $\mu \mathrm{L}$; v.o.); EtOAc - cinnamon ethyl acetate extract of old. The values represent the mean \pm standard error of the mean (E.P.M.) for 6 animals/group; ANOVA followed by Tukey. ${ }^{* p<0} .05$; ${ }^{* * *} p<0.001$ vs. Naive. The numbers above each column indicate percentage of locomotor activity (\% AL).

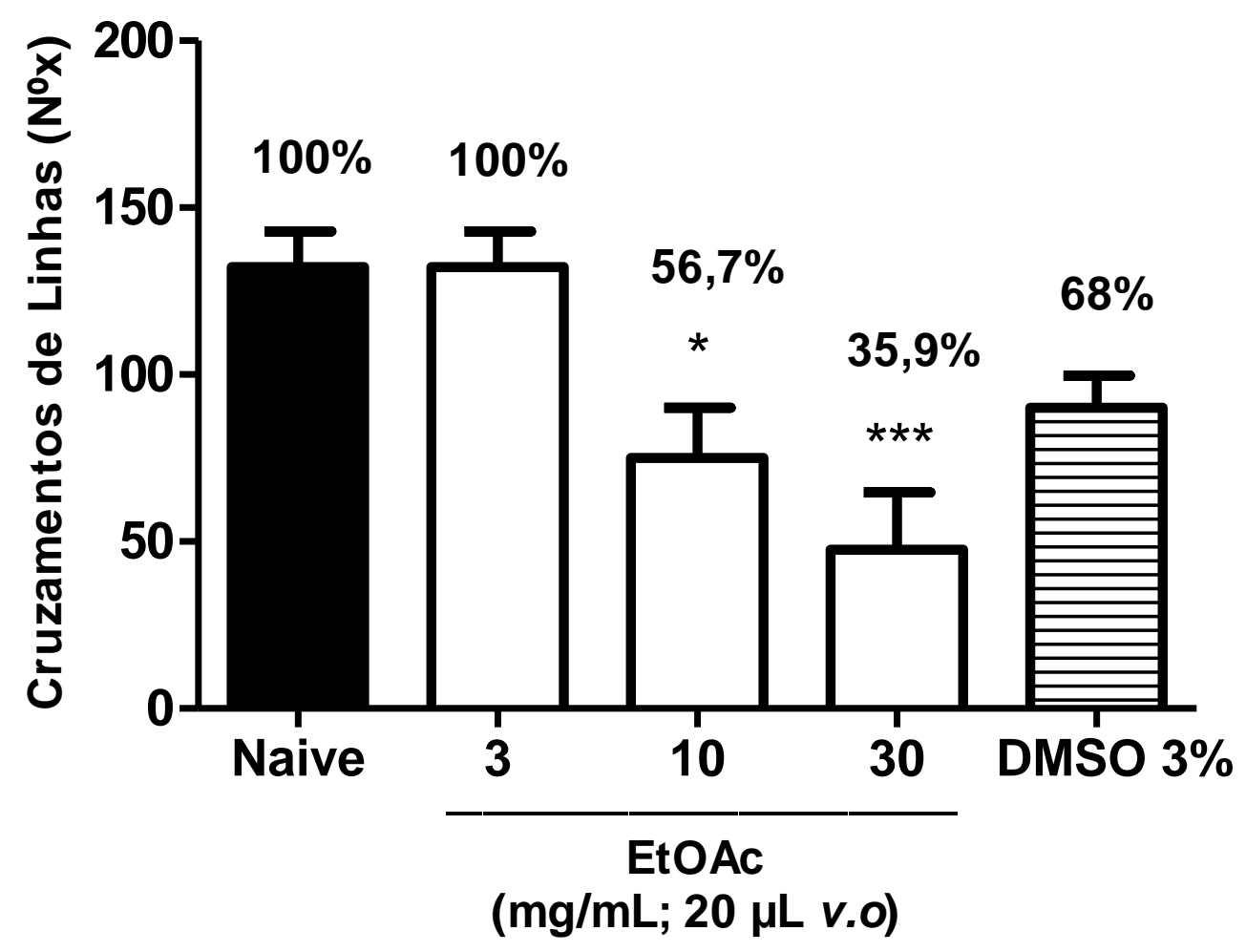

Source: Authors.

\subsubsection{Light-Dark Preference Test (Evaluation of ansiolitic activity)}

The Light \& Dark test showed that EtOAc at a dose of $30 \mathrm{mg} / \mathrm{mL} ; 20 \mu \mathrm{L}$ when given intraperitoneally (IP) has an anxiolytic effect similar to Diazepam IP control, since fish under the effect of the drugs increased their stay in the light zone, $(\mathrm{PZCEtOAc}=80.8 \%) ;(\mathrm{PZCDZP}=81.5 \%)$, as shown in Figure 2: 
Figure 2: Light \& Dark test of adult zebrafish (Danio rerio). Each column represents the mean \pm standard error ( $\mathrm{n}=6 / \mathrm{group}$ ). Naive - no treatments. Control - mineral water $(20 \mu \mathrm{L}$ v.o./ i.p. $)$. DZP-Diazepam $(5.0 \mathrm{mg} / \mathrm{mL} ; 20 \mu \mathrm{L}$ v.o. $)$ or $(2.5 \mathrm{mg} / \mathrm{mL} ; 20$ $\mu \mathrm{L}$ i.p.). ANOVA followed by Tukey test: ${ }^{*} \mathrm{p}<0.05 ; * * \mathrm{p}<0.01 ; * * * \mathrm{p}<0.001$ vs. Naive and control.

A

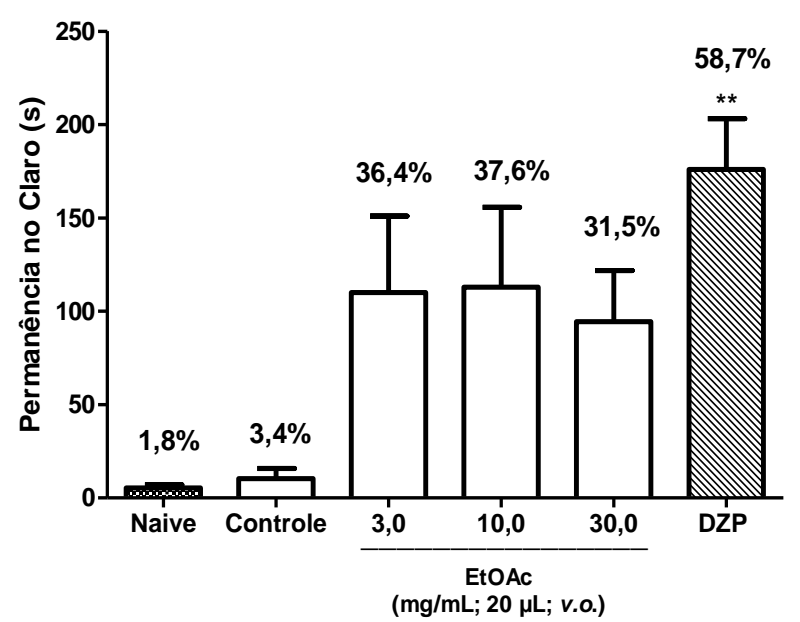

B

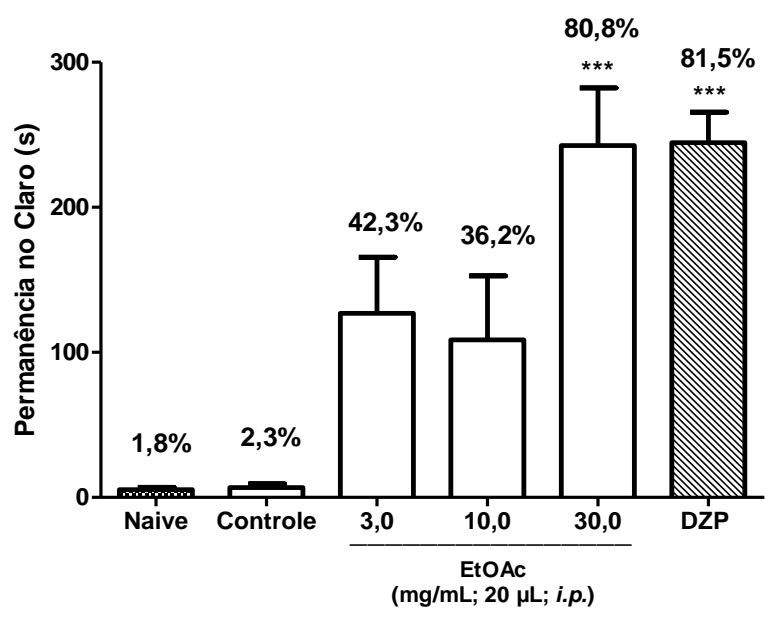

Source: Authors.

\section{Discussion}

Myconia represents one of the largest genera of the Melastomatacea family and with approximately 1000 species. Studies show that this genus has several biological activities such as analgesic, antimicrobial, fungicidal and trypanocidal effects (Cunha et al., 2006; Li et al., 2001; Pieroni et al., 2011; Torrão et al., 2012; Lemos Vasconcelos et al., 2003)

The ethanolic extract of cinnamon ethyl acetate (EtOAc) showed to have significant amounts of phenols, flavanoids of the flavones type, flavonols and xanthones; The flavanoids are flavanones, triterpenoids and alkaloids type. These results were also confirmed by Pieroni et al. (Pieroni et al., 2011) and Santos et al (Aurélio Figuereido Dos Santos et al., 2017), who showed the presence of these compounds in extracts of dried leaves in Myconia albicans and other species of this same genus. The phenolic compounds, because they have an antioxidant effect, are able to neutralize the activity of free radicals present in the body, and these are directly related to several chronic-degenerative diseases such as diabetes, cancer, inflammatory processes and cardiovascular diseases (Bessa et al., 2014), in addition to diseases of the central nervous system (Lajolo, 2009).

Artemia salina is a filtering crustacean that feeds basically on bacteria, unicellular algae, small protozoa and debris dissolved in the medium. A. salina is a kind of microcrustacean of the Anostraca order, used in this work as a bioindicator of toxicity. Studies prove the toxic action of several natural substances to this crustacean (Barroso Rios, 1995; Lagarto Parra et al., 2001; Martins et al., 2014; Scalco \& Munhoz, 2016; Widdows, 2009). Its use is easy to manipulate, besides having low economic cost (Nascimenlo et al., 2008). It was found that EtOAc has no toxic effect on Artemia salina, with no mortality of $50 \%$ of the animals. The study of Scalco (Scalco \& Munhoz, 2016) tested the toxicity of the methanolic extract of M. albicans in different concentrations, also using the Artemia salina for 24 hours. The results confirm the low toxicity of M. albicans. The toxicity tests are elaborated with the objectives of evaluating or predicting the toxic effects on biological systems and dimensioning the relative toxicity of the substances (Forbes \& Forbes, 1994).

For decades, animal models have been used in neuropsychopharmacology for pre-clinical studies, seeking to understand the pathophysiology and new drugs for the treatment of mental disorders (Nunes \& Hallak, 2014). The zebrafish (Dario regio) emerges as a new model for behavioral studies and molecular mechanisms of mental disorders due to its low cost and high genetic and physiological homology with humans (Mesquita et al., 2017). 
M. albicans extract, at doses of 10 and $30 \mathrm{mg} / \mathrm{mL}$, showed decreased locomotor activity in the open field model in zebrafish. Through the low motor activity and the reduction of the exploratory activity of the animal in relation to the new environment, a possible action of the extract in the central nervous system is signaled, interpreted as a possible anxiolytic effect (Taylor et al., 2010).

To evaluate this anxiolytic effect of EtOAc, the light \& dark preference test was used, in which the Zebrafish presents a behavior called scottotaxis which refers to the preference for dark environments. This fish species tends to remain about $80 \%$ of the time in the darker environment (Maximino et al., 2010, 2007).

Zebrafish treated with the highest dose of M. albicans extract had an anxiolytic effect when compared to control and Diazepam. Both showed a very similar length of stay in the clear zone. Thus, the fish that received the EtOAc stayed $80.8 \%$ of the time in the lighter zone, and the animals that received the Diazepam stayed for $81.5 \%$ of the time in the clear, against less than $4 \%$ in relation to the DMSO control and $1.8 \%$ of the naive. This effect can be justified by the large amount of phenolic and flavonoid compounds found in M. albicans, since these bioactive compounds have the ability to overcome the Blood-Brain Barrier, promoting a protective effect on the Central Nervous System through its antioxidant action and neuronal modulation (Lajolo, 2009). According to some authors, flavonoids have high affinity as binders of GABA A receptors in the Central Nervous System (Fernández et al., 2006; Hanrahan et al., 2011; Wasowski \& Marder, 2012), leading to the anxiolytic effect observed in zebrafish treated with ethanolic extracts of M. albicans.

\section{Conclusion}

The ethanolic extract of ethyl acetate from Myconia albicans (Old Cinnamon) presented, in its composition, several phenols and flavonoids with a good yield and low toxicity effect for Artemia salina. In Zebrafish models, M. albicans extract showed that the dose of $30 \mathrm{mg} / \mathrm{mL}$, both in the oral and intraperitoneal routes, presents an anxiolytic effect. However, further studies are needed in order to evaluate the main active compounds in Myconia albicans extract, in order to elucidate the anxiolytic action mechanisms present in this plant.

\section{References}

Figueireido dos Santos, M. A., Silva, M. A. P., Santos, A. C. B., Bezerra, J. W. A., Alencar, S. R., \& Barbosa, E. A. (2017). Atividades biológicas de Miconia spp. Ruiz \& Pavon (Melastomataceae Juss.). Gaia Scientia, 11(1), 157-170. http://dx.doi.org/10.21707/gs.v11.n01a12

Barroso Rios, F. J. (1995). Digestibilidade in vitro e toxicidade de lectinas vegetais para náuplios de Artmia sp. Dissertação de Mestrado , Programa de PósGraduação Em Bioquímica, Universidade Federal Do Ceará, 53(9), 1689-1699. https://doi.org/10.1017/CBO9781107415324.004

Bessa, N. G. F., Borges, J. C. M., Beserra, F. P., Carvalho, R. H. A., Pereira, M. A. B., Fagundes, R., \& Alves, A. (2014). Prospecção fitoquímica preliminar de plantas nativas do cerrado de uso popular medicinal pela comunidade rural do assentamento vale verde - Tocantins. Revista Brasileira de Plantas Medicinais, 15(Suppl.1), 692-707. https://doi.org/10.1590/S1516-05722013000500010

Bezerra, E. R., Alves Júnior, E. B., Diniz, A. F. A., Felício, I. M., Nóbrega, R. O., Alves, H. da S., \& Queiroz, M. do socorro R. de. (2017). Utilização de Benzodiazepínicos por usuários do sistema único de saúde. Biofarm, 13(17), 1983-4209. https://doi.org/10.1017/CBO9781107415324.004

Brasil. Ministério da Saúde. (2004). Agencia Nascional de Vigilência Sanitária - ANVISA, Resolução nº 90 , de 16 de Março de 2004. Diário Oficial [Da República Federativa Do Brasil], 2004.

Brasil. Ministério da Saúde. (2014). Agência Nacional de Vigilância Sanitária - ANVISA. RDC nº 26, de 13 de Maio de $2014,2014$.

Canedo, A., Rocha, T.L. (2021). Zebrafish (Danio rerio) using as model for genotoxicity and DNA repair assessments: Historical review, current status and trends. Science of The Total Environment, 762(144084), 1-17. https://doi.org/10.1016/j.scitotenv.2020.144084.

Celotto, A. C., Nazario, D. Z., De Almeida Spessoto, M., Gomes Martins, C. H., \& Cunha, W. R. (2003). Evaluation of the in vitro antimicrobial activity of crude extracts of three Miconia species. Brazilian Journal of Microbiology, 34(4), 339-340. https://doi.org/10.1590/S1517-83822003000400010

Cunha, W. R., Crevelin, E. J., Arantes, G. M., Miller Crotti, A. E., Andrade E Silva, M. L., Cardoso Furtado, N. A. J., \& Ferreira, D. D. F. (2006). A study of the trypanocidal activity of triterpene acids isolated from Miconia species. Phytotherapy Research, 20(6), 474-478. https://doi.org/10.1002/ptr.1881

Arruda, M. D.O.V., Soares, P. M., Honório, J. E. R., Lima, R. C. D.S., Chaves, E. M. C., Lobato, R. D. F. G., \& Vasconcelos, S. M. M. (2008). Activities of 
the antipsychotic drugs haloperidol and risperidone on behavioural effects induced by ketamine in mice. Scientia Pharmaceutica, 76(4), 673-687. https://doi.org/10.3797/scipharm.0810-11

Fernández, S. P., Wasowski, C., Loscalzo, L. M., Granger, R. E., Johnston, G. A. R., Paladini, A. C., \& Marder, M. (2006). Central nervous system depressant action of flavonoid glycosides. European Journal of Pharmacology, 539(3), 168-176. https://doi.org/10.1016/j.ejphar.2006.04.004

Ferreira, C., Monteiro, D. S., Costa, S., Felipe, R., \& Soares, S. (2017). Prevalência dos transtornos de ansiedade como causa de afastamento de trabalhadores. Revista Brasileira de Enfermagem, 71(suppl 5), 2344-2351. Retrieved from http://www.scielo.br/pdf/reben/v71s5/pt_0034-7167-reben-71-s5-2213.pdf

Figueredo, C. A., Gurgel, I. G. D., \& Gurgel Junior, G. D. (2014). A política nacional de plantas medicinais e fitoterápicos: Construção, perspectivas e desafios. Physis: Revista de Saúde Coletiva, 24(2), 381-400. https://doi.org/10.1590/S0103-73312014000200004

Forbes, V. E., \& Forbes, T. L. (1994). Ecotoxicology in theory and practice. Ecotoxicology series.

Garakani, A., Murrough, J. W., Freire, R. C., Thom, R. P., Larkin, K., Buono, F. D., \& Iosifescu, D. V. (2020). Pharmacotherapy of Anxiety Disorders: Current and Emerging Treatment Options. Frontiers in Psychiatry, 11(December), 1-21. https://doi.org/10.3389/fpsyt.2020.595584

Gebauer, D. L., Pagnussat, N., Piato, Â. L., Schaefer, I. C., Bonan, C. D., \& Lara, D. R. (2011). Effects of anxiolytics in zebrafish: Similarities and differences between benzodiazepines, buspirone and ethanol. Pharmacology Biochemistry and Behavior, 9(3), 480-486. https://doi.org/10.1016/j.pbb.2011.04.021

Hanrahan, J. R., Chebib, M., \& Johnston, G. A. R. (2011). Flavonoid modulation of GABA A receptors. British Journal of Pharmacology, 163(2), 234-245. https://doi.org/10.1111/j.1476-5381.2011.01228.x

Parra, A. L., Yhebra, R. S., Sardiñas, I. G, \& Buela, L. I. (2001). Comparative study of the assay of Artemia salina L. And the estimate of the medium lethal dose (LD50 value) in mice, to determine oral acute toxicity of plant extracts. Phytomedicine, 8(5), 395-400. https://doi.org/10.1078/0944-7113-00044

Sanches, S. D., \& Lajolo, F. M. (2009). Flavonoides e suas relação com doenças do Sistemas Nervoso Central. Nutrire: Revista Da Sociedade Brasileira De Alimentação E Nutrição, 36(2), 123-135.

Lemos, A. R., Rêgo Junior, N. O., São José, A. R., Pereira, M. L. A., \& Silva, M. V. da. (2011). Atividade antioxidante e correlação com fenólicos totais em genótipos de Urucum (Bixa orellana L). Revista Do Instituto Adolfo Lutz, 70(1), 62-68. https://doi.org/10.53393/rial.2011.v70.32592

Li, X. C., Jacob, M. R., Pasco, D. S., ElSohly, H. N., Nimrod, A. C., Walker, L. A., \& Clark, A. M. (2001). Phenolic compounds from Miconia myriantha inhibiting Candida aspartic proteases. Journal of Natural Products, 64(10), 1282-1285. https://doi.org/10.1021/np010172p

Lima, T. C., Matos, S. S., Carvalho, T. F., Silveira-Filho, A. J., Couto, L. P. S. M., Quintans-Júnior, L. J., \& Silva, F. A. (2020). Evidence for the involvement of IL-1 $\beta$ and TNF- $\alpha$ in anti-inflammatory effect and antioxidative stress profile of the standardized dried extract from Miconia albicans Sw. (Triana) Leaves (Melastomataceae). Journal of Ethnopharmacology, 259(December 2019), 112908. https://doi.org/10.1016/j.jep.2020.112908

Lorenzi, H., \& Matos, F. J. de A. (2002). Plantas medicinais no Brasil: nativas e exóticas cultivadas. Instituto Plantarum.

Magalhães, F. E. A., De Sousa, C. Á. P. B., Santos, S. A. A. R., Menezes, R. B., Batista, F. L. A., Abreu, Â. O., \& Campos, A. R. (2017). Adult Zebrafish (Danio rerio): An Alternative Behavioral Model of Formalin-Induced Nociception. Zebrafish, 14(5), 422-429. https://doi.org/10.1089/zeb.2017.1436

Martins, M. D. R., Arantes, S., Candeias, F., Tinoco, M. T., \& Cruz-Morais, J. (2014). Antioxidant, antimicrobial and toxicological properties of Schinus molle L. essential oils. Journal of Ethnopharmacology, 151(1), 485-492. https://doi.org/10.1016/j.jep.2013.10.063

Maximino, C., de Brito, T. M., da Silva Batista, A. W., Herculano, A. M., Morato, S., \& Gouveia, A. (2010). Measuring anxiety in zebrafish: A critical review. Behavioural Brain Research, 214(2), 157-171. https://doi.org/10.1016/j.bbr.2010.05.031

Maximino, C., Marques, T., Dias, F., Cortes, F., Taccolini, I., Pereira, P., \& Jr., A. (2007). A Comparative Analysis of the Preference for Dark Environments in Five Teleost. International Journal of Comparative Psychology.

Mesquita, D. da silva, Barriga, J. R. de M., \& Honório Junior, J. E. R. (2017). Zebrafish: um peixe que está conquistando a ciência. Revista Interagir, 13, 4650 .

Meyer, B. N., Ferrigni, N. R., \& Putnam, J. E. (1982). Brine shrimp: A convenient general bioassay for active plant constituents. Planta Medica, 41(1), 31-34. https://doi.org/10.1055/s-2007-971236

Mufford, M.S., van der Meer, D., Andreassen, O.A., Ramesar, R., Stein, D.J., \& Dalvie, S. (2021) A review of systems biology research of anxiety disorders. Braz J Psychiatry,43(4), 414-423. https://doi.org/10.1590/1516-4446-2020-1090.

Nascimenlo, J. E., Melo, A. F. M., Lima E Silva, T. C., Veras Filho, J., Santos, E. M., Albuquerque, U. P., \& Amorim, E. L. C. (2008). Estudo Fitoquímico e bioensaio toxicológico frentea larvasde Artemia salina Leach.detrěs espécies medicinais do gěnero Phyllanthus (Phyllanthaceae). Revista de Ciencias Farmaceuticas Basica e Aplicada, 29(2), 145-150.

Nunes, E. A., \& Hallak, J. E. C. (2014). Modelos animais em psiquiatria: Avanços e desafios. Revista Latinoamericana de Psicopatologia Fundamental, 17(3), 528-543. https://doi.org/10.1590/1415-4714.2014v17n3p528-10

Penninx, B. W., Pine, D. S., Holmes, E. A., \& Reif, A. (2021). Anxiety disorders. The Lancet, 397(10277), 914-927. https://doi.org/10.1016/s01406736(21)00359-7

Pieroni, L. G., De Rezende, F. M., Ximenes, V. F., \& Dokkedal, A. L. (2011). Antioxidant activity and total phenols from the methanolic extract of miconia albicans (Sw.) triana leaves. Molecules, 16(11), 9439-9450. https://doi.org/10.3390/molecules16119439

Reis, B. V., Batista, F. dos S., Silva, L. M., Matos, M. de, Amorim, M. C. M., Teixeira, M. R., \& Cunha, M. F. (2017). Desenvolvimento de líquido oral para 
Research, Society and Development, v. 11, n. 1, e50811125048, 2022

(CC BY 4.0) | ISSN 2525-3409 | DOI: http://dx.doi.org/10.33448/rsd-v11i1.25048

veícular a associação de Hypericum perforatum L e Passiflora Incarnatal L. Pesquisa $e \quad$ Ação, $3(1)$. https://revistas.brazcubas.br/index.php/pesquisa/article/view/261

Sborgi, S.M.S., Fernandes, L.C., Santos, A.G., Ferro, M. M. \& Miyoshi, E. (2021). Atividade ansiolítica do ácido ferúlico no teste claro-escuro em peixeszebra. Pesquisa, Sociedade e Desenvolvimento,10(11), 582101119894. https://doi.org/10.33448 / rsd-v10i11.19894.

Scalco, C. D. N., \& Munhoz, C. L. (2016). Estudo fitoquímico e avaliação da toxicidade aguda dos extratos brutos das plantas Alternanthera brasiliana (L.) Kuntze, Chenopodium ambrosioides L. E Miconia albicans sw. Triana. Journal of Agronomic Sciences, 5(2), 181-194. https://doi.org/10.1590/S0102$695 \times 2010000100006$

Slinkard, K., \& Singleton, V. (1977). Total phenol analysis: automation and comparison with manual methods. American Journal of Enology and Viticulture, 28, 49-55. https://doi.org/10.1016/j.carbpol.2011.06.030

Sousa, E. O., Miranda, C. M. B. A., Nobre, C. B., Boligon, A. A., Athayde, M. L., \& Costa, J. G. M. (2015). Phytochemical analysis and antioxidant activities of lantana camara and lantana montevidensis extracts. Industrial Crops and Products, 70, 7-15. https://doi.org/10.1016/j.indcrop.2015.03.010

Stewart, A., Gaikwad, S., Kyzar, E., Green, J., Roth, A., \& Kalueff, A. V. (2013). Modeling Anxiety in Zebrafish Review. Neuropharmacology, 62(1), 135143. https://doi.org/10.1016/j.neuropharm.2011.07.037.Modeling

Taylor, J. L., Rajbhandari, A. K., Berridge, K. C., \& Aldridge, J. W. (2010). Dopamine receptor modulation of repetitive grooming actions in the rat: Potential relevance for Tourette syndrome. Brain Research, 1322, 92-101. https://doi.org/10.1016/j.brainres.2010.01.052

Torrão, A. S., Café-Mendes, C. C., Real, C. C., Hernandes, M. S., Ferreira, A. F. B., Santos, T. O., \& Britto, L. R. G. (2012). Different Approaches, One Target: Understanding Cellular Mechanisms of Parkinson's and Alzheimer's Diseases. Revista Brasileira de Psiquiatria, 34, 194-218. https://doi.org/10.1016/j.rbp.2012.08.004

Vasconcelos, M. A.Lemos, Ferreira, D. da S., Andrade e Silva, M. L., Veneziani, R. C. S., \& Cunha, W. R. (2003). Analgesic effects of crude extracts of Miconia albicans (Melastomataceae). Bollettino Chimico Farmaceutico, 142(8), 333-335. PMID: 15040462.

Vasconcelos, Maria Anita L., Royo, V. A., Ferreira, D. S., Miller Crotti, A. E., Andrade E Silva, M. L., Carvalho, J. C. T., \& Cunha, W. R. (2006). In vivo analgesic and anti-inflammatory activities of ursolic acid and oleanoic acid from Miconia albicans (Melastomataceae). Zeitschrift Fur Naturforschung Section C Journal of Biosciences, 61(7-8), 477-482. https://doi.org/10.1515/znc-2006-7-803

Wasowski, C., \& Marder, M. (2012). Flavonoids as GABAA receptor ligands: the whole story? Journal of Experimental Pharmacology, 9. https://doi.org/10.2147/jep.s23105

Widdows, J. (2009). Marine and https://doi.org/10.1002/9781444313512.ch9

Estuarine Invertebrate Toxicity Tests. In Handbook of Ecotoxicology (pp. 145-166). 